Nippon Suisan Gakkaishi $\quad$ 80(6), 1003 (2014)

\title{
ミニシンポジウム記録 水産物の生産・加工・流通段階を保障するリスク管理研究の最新動向
}

\section{1. 農林水産物の生産加工流通段階における リスク管理技術}

\author{
川本伸一 \\ 独農研機構食品総合研究所
}

1. Techniques for ensuring the safety of agricultural products in the food chain

SHINICHI KAWAMOTO

National Food Research Institute, NARO, Tsukuba, Ibaraki 305-8642, Japan

\section{1. はじめに}

最近の食中毒菌による大規模集団食中毒発生や農薬な ぞの有害化学物質の食品中への混入, さらには原発事故 による放射性物質の污染など食品安全に関する事故打よ び偽装表示等の食品の信頼に関する事件の多発は, 消費 者に食品の安全・信頼に対して強い不安感を与えると共 に食品業界全体に対する不信感をいだかせている。最近 では，生鮮食品やRTE（Ready To Eat：調理せずにす ぐ食べられる）食品などの非加熱食品の消費が伸びてお り, これらの食品では, 微生物安全性の確保が極めて重 要となる。また, 女性の社会進出, 老人家庭の増加など の社会環境の変化により, 現在では, 家庭における調理 の簡素化や調理機会の減少傾向が進行しており, 食品工 場や外食施設など家庭以外で大量加工，調理された非加 熱食品の利用機会が増加している。このため，広域で大 規模な食中毒事件が発生するリスクも高まっている。1) さらに, 我が国は, 超高齢社会となり, 食中毒菌に対し て感受性が高い健康弱者（高齢者，幼児，生活習慣病罹 患者など）が増加している。

\section{2. 食品の安全性確保}

食品中の危害要因を完全に取り除くことは困難であ り，「リスクゼロの食品はありえない」というのが国際 共通認識である。食品の安全確保は, 危害要因を低減 し、リスクを社会的に許容される範囲内に抑えることが 目標となっている。現在では, 生産現場から食卓まで必 要かつ適切なりスク管理措置をとること, すなわち, 生
産，加工，流通を経て消費に至るフードチェーンの各段 階で衛生規範（指針, ガイドライン）を適用して食品安 全を確保する姿勢が食品の安全確保には重要とされてい る。具体的には, GAP (Good Agricultural Practice : 農業生産工程管理）で安全な原材料を生産し, GMP （Good Manufacturing Practice：適正製造規範）や SSOP (Sanitation Standard Operating Procedures: 衛 生標準作業手順書) による一般衛生管理プログラムで衛 生的な作業，製造環境を確保して，HACCP（Hazard Analysis and Critical Control Point : 危害分析重要管理 点)2や，より包括的な ISO22000 システム（http:// www.iso.org / iso / home / standards / management-standards/iso22000.htm）で食品の衛生管理を行い，食品の 安全性を保証するシステムである。

\section{3. リスク管理技術開発}

農林水産省では, 平成 20 年から平成 24 年度までの 5 年間, レギュラトリーサイエンス ${ }^{3}$ による農産物・食品 の安全確保に向けた大型の委託プロシェクト「生産工程」 （略称）を実施した。このプロジェクトの研究目標は, 農畜水産物の生産から流通・加工工程に抢いて重要度が 高い危害要因（かび毒や病原微生物などを対象）につい て, 生産・流通・加工工程における動態の解明や簡易で 迅速な検出技術の開発を行い，それらをもとに危害要因 ごとに，現場で実施可能なリスク低減技術を開発するこ とである。本プロジェクトでは, リスク管理のための指 針を強化する重要な科学的知見が得られ, また, 現場に 普及可能な数々のリスク低減技術が開発されている。4)

\section{文献}

1）川本伸一. 生鮮野菜の微生物安全性確保のための国内外の 取り組み。是微誌 2013; 30: 104-107.

2) Recommended international code of practice, General principles of food hygiene CAC/RCP 1-1969, Rev. 4-2003.

3）川本伸一. 食品安全のためのレギュラトリーサイエンス. ソフト・ドリンク技術資料 2010; 162: 71-91.

4）研究成果 522 生産・流通・加工工程における体系的な危 害要因の特性解明とリスク低減技術の開発 [カビ毒・病原 微生物（第 2 編）］．農林水産省技術会議事務局. 東京. 2014; 156-180. 